\title{
The Interaction Between BMI, Weight Criticism, Weight Bias and Psychological and Relational Outcomes Within Marriage
}

Robert Carels ( $\sim$ carelsr14@ecu.edu )

East Carolina University https://orcid.org/0000-0003-4067-5750

\section{J. Caroline Miller}

East Carolina University

Reid Hlavka

East Carolina University

Abigail MT Shonrock

East Carolina University

\section{Research Article}

Keywords: Weight stigma, weight criticisms, mate value psychological distress, self-esteem, marital satisfaction, sexual intimacy

Posted Date: August 11th, 2021

DOl: https://doi.org/10.21203/rs.3.rs-718532/v1

License: (c) (i) This work is licensed under a Creative Commons Attribution 4.0 International License. Read Full License 


\section{Abstract}

Purpose: To examine 1) whether a wife's BMI interacts with either her husband's weight stigma or 2) her perceived weight criticisms from her husband predict husbands' and wives' psychological and relational outcomes.

Methods: The study sample consisted of 209 currently married men and women in a heterosexual relationship. Participants were drawn from an online survey platform (Qualtrics, Inc. Provo, UT) designed to approximate the US population on age, race, and region of the country. Online measures assessed husbands' weight stigma, wives' perceived weight criticisms from husband, and husbands' and wives': 1) relationship satisfaction, 2) sexual intimacy, 3) self-esteem, 4) depressive symptoms, and 5) perceptions of a desirable or ideal mate.

Results: Wives' BMI interacted with husbands' weight stigma to predict 1) mate value for husbands and wives and 2) marital satisfaction for husbands. The same pattern was noted with interaction of wives' $\mathrm{BMI}$ and perceptions of husbands' weight related criticisms. The interaction reflected that higher wife BMI and higher husband weight stigma or wife perceived weight-related criticism predicted lower marital satisfaction, greater depression, and lower perceptions of a desirable or an ideal mate. Lower BMI was not associated with outcomes regardless of the husbands' weight stigma or wives' perceived weightrelated criticisms.

Conclusion: To understand the impact of weight stigma and weight related criticisms on perceptions of a desirable or ideal mate and marital outcomes, it is important to examine the interaction with partner's BMI.

Level of Evidence: III: Evidence obtained from cohort or case-control analytic studies.

\section{Introduction}

The harmful consequences of weight stigma, defined as discrimination or stereotyping based on a person's weight or negative attitudes about a person because of their weight, have been well-documented (1). An important area to study in weight stigma is the marital relationship. Research has established that weight-related factors can significantly influence perceptions of mate value (2). Similarly, intimate relationships have been identified as a common source of weight stigmatizing experiences (3), however more research is needed in this important area of inquiry.

Generally, relative to men, young adult women are more likely to receive weight-related comments from their romantic partner and these comments are associated with diminished physical and mental health (4). Similarly, among college women, lower relationship satisfaction has been associated with weightrelated comments and criticisms from romantic partners (5). Additionally, in prior research examining wives using structural equation modelling, analyses revealed that wives' internalized weight bias and other weight-related concerns, as well as perceived husbands' weight-related suggestions or criticisms 
had both direct and indirect effects through perceived mate value on wives' psychological distress, relationship satisfaction, and sexual intimacy (6). In a related study examining husbands, structural equation modeling analyses revealed that husbands' weight stigma and IWB were indirectly linked to husbands' and wives' relationship satisfaction and sexual intimacy through weight-related concerns/criticisms and, to a lesser extent, perceptions of a desirable or ideal mate (7). Also, a husband's IWB and weight stigma had a direct effect on his depressive symptoms and self-esteem. These studies highlight the prominent role that weight stigma and weight related comments and criticisms have in perceptions of a desirable or ideal mate as well as psychological and relationship well-being.

Despite the important contribution of earlier research in this area, few publications have examined whether a spouse's weight interacts with their partner's weight-related criticisms or their partner's weight stigma to predict psychological and relational outcomes. While past research indicates that an individual's own weight stigma is only weakly associated with their weight (8), no research has examined whether, for example, a husband's weight stigma or the wife's weight-related criticisms from her husband interact with his wife's BMI to predict psychological and relational outcomes. Extant literature indicates that women are more likely than men to receive weight-related comments from their romantic partner (4), thus we have elected to focus on the wife's BMI in this investigation. Also, heterosexual couples were exclusively chosen given that research suggests varying relational-, body- and weight-based experiences among sexual minorities, particularly for gay men and lesbian women (e.g., 9). We hypothesize that a wife's BMI will interact with her husband's weight stigma to predict both his and her psychological (i.e., self-esteem and depressive symptoms) and relational outcomes (i.e., marital satisfaction, sexual intimacy, and perceived mate value). Similarly, we hypothesize that a wife's BMI will interact with her husband's weight-related criticisms to predict his and her psychological and relational outcomes. Specifically, when a wife's BMI is greater and her husband's stigma or her weight-related criticisms from her husband are greater, the negative impact on the husband's and wife's psychological and relational outcomes will be greater than when the wife's BMI is lower and/or the husband's stigma and weightrelated criticisms is lower.

\section{Methods}

\section{Participants}

The study sample consisted of 209 currently married men and women in a heterosexual relationship. For men, $M_{\text {age }}=49.0, S D_{\text {age }}=14.4$, were $11 \%$ African American, 4\% Asian American, 79\% European American, and $6 \%$ other/multi-racial. Fifty-two percent of participants reported that they had a four-year college degree or higher, and $76 \%$ of participants reported that they earned an annual household income over $\$ 50,000$. Participants also reported a duration of marriage of $M_{\text {years }}=20.4, S D_{\text {years }}=14.8$ years with a range of 0 to 59 years. Average BMl, derived from self-reported height and weight, was 28.1 ( $S D=5.7$; range 15.8-57.8). For women, $M_{\text {age }}=48.9, S D_{\text {age }}=14.3$, were $10 \%$ African American, $3 \%$ Asian American, 77\% European American, and 10\% multi-racial. Eighty-one percent of participants reported that 
they had completed an associate's degree or higher. Average BMI, derived from self-reported height and weight, was 27.4 ( $S D=6.4$; range 17.2-50.8). Regarding dieting, in this study, $30.3 \%$ of the women "mostly" or "definitely" indicated that they are on a diet. Participants were drawn from an online survey platform sample (Qualtrics, Inc. Provo, UT) designed to approximate the US population on age, race, and region of the country.

\section{Procedure}

Husbands and wives completed separate informed consent and self-report measures. Husbands and wives were not able to view their partner's submitted answers. Participants who completed the Qualtrics panel received $\$ 10$ in e-rewards currency. Data collection began on 5/11/2018 and ended on 6/4/2018. There were two validity questions each (four per dyad). Questions included "for this item/statement select strongly agree." All cases in our analyses were considered valid due to Qualtrics online survey platform exclusion criteria (cases not married, not heterosexual, and incorrectly answering all four validity questions included in the survey). This study was approved by the East Carolina University, University and Medical Center IRB (UMCIRB 18-000554). There was no debriefing outside of the online consent form. all analyses were conducted using the Statistical Package for Social Sciences, Version 26 (SPSS).

\section{Measures}

Demographic and Weight Information. Participants were asked to report their age, sex, ethnicity, height, weight, education, annual household income, length of their marriage, length of cohabitation, number of children, and if they were trying to lose weight.

Weight bias. This investigation used the Dislike subscale of the Anti-Fat Attitudes Questionnaire (AFA; (10) to assess stigmatized beliefs towards persons with obesity. In the current investigation, internal consistency for husbands was good for the Dislike $(a=.94)$, subscale.

Mate value perceptions. The Partner Ideals Scale was adapted from Fletcher, Simpson, Thomas, and Giles (11). The scale assesses three subscales: warmth and trustworthiness, attractiveness and vitality and status and resources (11). For the current study, wives reported how their husband would rate them as a mate (i.e., wife's rating of her mate value) and their perceived match to their husband's ideal mate (i.e., wife's rating of how she matches her husband's ideal mate), while husbands rated their wife as a mate (i.e., husband's rating of his wife's mate value) and the extent to which their wife meets their expectations relative to their ideal partner (i.e., husband's rating of how his wife matches his ideal mate).

Husband's suggestions/criticisms. Weight-related criticism from romantic partners was assessed using a 4-item measure from Befort (12). Wives rated the frequency of comments from their partner, while husbands rated the frequency of comments directed toward their partner, on a 6-point scale ranging from 1 (never) to 6 (all the time).

Depressive Symptoms and Self-Esteem. Participants completed the Center for Epidemiological Study of Depression (CES-D), a 20-item, self-report measure used to assess participants' depressive symptoms 
(13). Participants also completed the Rosenberg Self-Esteem Scale, a 10-item self-report measure to assess overall self-esteem (14).

Marital Satisfaction and Sexual Intimacy. Participants completed the Couples Satisfaction Index (CSI), a 16-item measure designed to assess one's satisfaction in a relationship (15). Sexual intimacy was assessed using the 6-item subscale from the Personal Assessment of Intimacy in Relationships (PAIR; (16).

\section{Results}

Multiple linear regression analysis was used to examine whether a husband's weight stigma and his wife's perceived weight-related criticism interacted with the wife's BMI to predict psychological and relationship outcomes. Correlations among variables are reported elsewhere (7).

\section{Husband Outcome Variables}

Multiple linear regression analyses examining wife BMI, husband weight stigma, and the interaction between wife $\mathrm{BMI}$ and husband weight stigma on husband outcome variables were performed. There were no main effects for BMI (see table 1 for husband outcomes). Greater husband weight stigma predicted lower husband's rating of how his wife matches his ideal mate. There were also significant interactions between wife BMI and husband weight stigma on husband depression, marital satisfaction, husband's rating of how his wife matches his ideal mate, and husband's rating of his wife's mate value. As wife BMI increased, higher husband weight stigma predicted higher depressive symptoms, lower marital satisfaction, lower husband's rating of how his wife matches his ideal mate, and lower husband's rating of his wife's mate value. Lower wife BMI and/or lower husband weight stigma was not associated with outcomes regardless of the husband's weight stigma. See Figure I for an illustrative figure of the interaction between wife BMl, husband stigma, ideal mate ratings.

Next, analyses examined wife BMI and wife perceived weight-related criticism from her husband on husband outcome variables. Higher wife perceived weight-related criticism from her husband predicted lower husband's rating of how his wife matches his ideal mate and lower husband's rating of his wife's mate value. There were also significant interactions on husband's marital satisfaction, husband's rating of how his wife matches his ideal mate and husband's rating of his wife's mate value. As wife BMI increased, higher perceived weight-related criticism from husbands predicted lower husband marital satisfaction, lower husband's rating of how his wife matches his ideal mate, and lower husband's rating of his wife's mate value. Lower BMI and/or lower husband's perceived weight-related criticisms were not associated with husband's rating of how his wife matches his ideal mate and husband's rating of his wife's mate value. Of interest, husbands' marital satisfaction was significantly influenced by wives' perceived weight-related criticism among women with higher BMI.

\section{Wife Outcome Variables}


Multiple linear regression analyses examining wife BMI, husband weight stigma, and the interaction between wife $\mathrm{BMI}$ and husband weight stigma on wife outcome variables were performed. There were no main effects for wife BMI or husband weight stigma (see table 2 for wife outcomes). However, there were significant interactions for the wife's rating of her mate value and wife's rating of how she matches her husband's ideal mate. As wife BMI increased, higher husband weight stigma predicted lower wife's rating of her mate value and lower wife's rating of how she matches her husband's ideal mate. Lower wife BMI and/or lower husband weight stigma were not associated with wife's rating of her mate value and wife's rating of how she matches her husband's ideal mate.

Next, analyses examined wife BMI, her perceived weight-related criticisms from her husband, and the interaction between wife BMI and perceived weight-related criticisms to predict wife outcomes. There were main effects, such that higher BMI and higher perceived weight-related criticism from one's husband predicted lower wife's rating of her mate value and lower wife's rating of how she matches her husband's ideal mate. As wife BMI increased, higher husband's perceived weight-related criticisms predicted lower wife's rating of her mate value and lower wife's rating of how she matches her husband's ideal mate. Lower BMI and/or lower husband's perceived weight-related criticisms was not associated with wife's rating of her mate value and wife's rating of how she matches her husband's ideal mate. All other main effects and interactions were not significant.

\section{Discussion}

This investigation examined whether a wife's BMI interacts with her perceived husband's weight-related criticisms or her husband's weight stigma to predict psychological and relational outcomes. Several interactions between 1) wives' BMI and husbands' weight stigma and 2) a wife's BMI and her perceived weight-related criticisms from her husband were significant. Not only did 1) wives' BMI and husbands' weight stigma and 2) a wife's BMI and perceived husband weight related criticisms significantly predict a husband's rating of how his wife matches his ideal mate and lower husband's rating of his wife's mate value, but they also predicted husband ratings of depression and marital satisfaction. Therefore, husbands who have negative attitudes toward heavier people, in general, or perhaps share those attitudes as weight related criticisms with their wife, not only view their wife as a less a desirable or ideal mate, but also have lower marital satisfaction. It is less clear why a husband's weight stigma may interact with his wife's BMI to predict his own depression. However, there is a long-standing relationship between marital satisfaction and depression (17).

Alternatively, the interaction of a wife's BMI and her perceived husband's weight-related criticisms, along with the interaction of wives' BMI and husbands' weight stigma never produced main effects for wife outcomes in the absence of an interaction effect. The interaction effects were only observed for a wife's rating of her mate value and a wife's rating of how she matches her husband's ideal mate. These interactions yielded the characteristic pattern observed in Figure I. These mate value ratings appeared unaffected or only modestly negatively affected by the husband's weight stigma or perceived weight related criticisms when the wife's weight was lower; however, when the wife's weight was heavier, as 
husband's weight stigma or perceived weight related criticisms increased, the wife's rating of herself as a desirable or ideal mate were greatly diminished. Several interpretations are possible. First, as a wife's BMI increases, weight related comments may be harder to dismiss or may have a greater impact on a wife's perceptions of herself as a desirable or ideal partner. Second, as a wife's BMI increases, she may internalize the weight stigma and view herself as an undesirable or less than ideal mate. The interaction between wife's BMI and her husband's weight stigma may suggest that when a wife is heavier, perhaps a husband's weight stigma is shared with his wife in various ways, including but not limited to weight related criticisms, in a manner that diminishes her perceptions of herself as a desirable or ideal partner. Again, wives' perception of her mate value and how she matches her husband's ideal mate has less impact when a wife is thinner. Overall, this is consistent with previous research, whereby women are frequently subjected to and experience consequences from weight-related comments from their partner $(4-6)$.

This report offers insight into the interplay of wife BMI and husband weight-related attitudes and behaviors within a relationship among husbands and wives in a heterosexual relationship. Because weight bias is nearly ubiquitous and weight-related comments are all too common, these findings are of great importance. While weight stigma may only be weakly associated with an individual's actual weight, it may have a great impact on perceptions of being an ideal or desirable mate and marital satisfaction when a partner's weight is concerned. It is the unfortunate combination of weight stigma and expression of this stigma through critiques and higher wife BMI that subjects the couple to further adverse outcomes. Husbands and wives may benefit from marital counseling and challenging weight bias and weight ideals in pursuit of a healthier relationship. Exploration of interventions for couples may also be beneficial. Taken together, these findings suggest that to truly understand the impact of weight stigma and weight related criticisms in marriage, it is important to consider both a spouse's attitudes and their partners BMI.

\section{Strengths and Limitations}

The current study has several strengths. First, these findings extend research reporting the negative impact of higher BMI and weight stigma in dating relationships to the negative impact of IWB in marital relationships $(1,18)$. Second, participants were drawn from an online survey platform designed to approximate the US on age, race, and region of the country, thus our sample is likely more representative than many convenience samples of weight stigma.

Limitations of this study include the associational nature of the data, which precludes causal interpretations. However, our findings are consistent with numerous past studies which have demonstrated the harmful consequences of weight bias, including in intimate relationships (1). Also, while this investigation's sample was designed to approximate the U.S. population on several key demographics (i.e., age, race, region of the country), the sample was somewhat lacking in lower SES individuals. Further, because the sample was collected primarily online, we had to rely on self-reported 
height and weight to calculate BMI. Finally, the study focused on heterosexual married couples and the findings may not apply to same sex married couples.

\section{What is already known on this subject?}

Intimate relationships have been identified as a common source of weight stigmatizing experiences. Relative to men, women are more likely to receive weight-related comments from their romantic partner and these comments are associated with diminished physical and mental health.

\section{What does this study add?}

This study is one of the first to examine interactions between wives BMI and husbands' weight stigma and wives' BMI and her perceived weight-related criticisms. These findings suggest that to truly understand the impact of weight stigma and weight related criticisms in marriage, it is important to consider both a spouse's attitudes and their partners BMI.

\section{Declarations}

\section{Compliance with Ethical Standards}

Conflicts of interest: The authors have no conflicts of interest to declare that are relevant to the content of this article

Funding: The authors did not receive support from any organization for the submitted work.

Ethical approval: This study was performed in line with the principles of the Declaration of Helsinki. Approval was granted by the Ethics Committee of East Carolina University (UMCIRB 18-000554).

Informed consent: Informed consent was obtained from all individual participants included in the study.

\section{References}

1. Puhl RM, Heuer CA. The stigma of obesity: A review and update. Obesity. 2009;17(5):1-24.

2. Carels RA, Rossi J, Solar C, Selensky JC. Changes in perceived mate value and weight bias associated with former obesity status. Stigma and Health. 2018;3(4):338.

3. Pearl RL, Wadden TA, Tronieri JS, Chao AM, Alamuddin N, Bakizada ZM, et al. Sociocultural and Familial Factors Associated with Weight Bias Internalization. 2018;11(2):157-64.

4. Eisenberg ME, Franz R, Berge JM, Loth KA, Neumark-Sztainer D. Significant others' weight-related comments and their associations with weight-control behavior, muscle-enhancing behavior, and emotional well-being. Families, Systems, \& Health. 2017;35(4):474.

5. Sheets VA, K.;. Are romantic partners a source of college students' weight concerns? Eating Behaviors. 2005;6(1):1-9. 
6. Carels RA, R.; Selenksy, J.; Solar, C; Rossi, J; Miller, J.C. Ellis J. The associations between wives' internalized weight bias and other weight-related concerns, perceived husbands' weight-related comments, perceived mate value, and psychological and relationship outcomes. Stigma and Health. 2020;5(3), 258.

7. Carels RA, Miller JC, Hlavka R, Selensky J, Shonrock AMT, Ellis JM. The Association Between Husbands' Weight Bias and Related Concerns and Husbands' and Wives' Psychological and Relationship Outcomes. Body Image 2020; 35, 11-21.

8. Durso LE, Latner JD. Understanding self-directed stigma: Development of the Weight Bias Internalization Scale. Obesity. 2008;16 (2):s80-s6.

9. Markey CN, Markey PM, August KJ, Nave CS. Gender, BMI, and eating regulation in the context of same-sex and heterosexual couples. Journal of behavioral medicine. 2016;39(3):398-407.

10. Crandall CS. Prejudice against fat people: Ideology and self-interest. Journal of Personality and Social Psychology. 1994;66 (5):882-94.

11. Fletcher GJ, Simpson JA, Thomas G, Giles L. Ideals in intimate relationships. Journal of personality and social psychology. 1999;76(1):72-9.

12. Befort CRK, S.E..; Hull-Blanks, E.;Nicpon, M.F.;Huser, L;Solensberger, S. Body image, self-esteem, and weight-related criticism from romantic partners. Journal of College Student Development. 2011;42(5): 407-19.

13. Radloff LS. The CES-D Scale: A self-report depression sacel for research in the general population. Applied Psychological Measurement. 1977;1 (3):385-401.

14. Rosenberg M. Self-esteem scale. In: Robinson JP, Shaver PR, editors. Measures of social psychological attitudes. Ann Arbor: Survey Research Center for Social Research; 1983. p. 81-3.

15. Funk JL, Rogge RD. Testing the ruler with item response theory: Increasing precision of measurement for relationship satisfaction with the Couples Satisfaction Index. Journal of Family Psychology. 2007;21:572-83.

16. Schaefer MT, Olson DH. Assessing intimacy: The PAIR inventory. Journal of marital and family therapy. 1981;7(1):47-60.

17. Beach SR, Sandeen E, O'Leary KD. Depression in marriage: A model for etiology and treatment: Guilford Press; 1990.

18. Carels RA, Rossi FA, Solar C, Selensky J. Change in perceived mate value and weight bias associated with former obesity status. Stigma and Health. 2018 3(4): 338.

\section{Tables}


Table 1

Main effects and interactions for husband outcome variables

\begin{tabular}{|c|c|c|c|c|c|c|c|c|}
\hline \multirow{2}{*}{$\begin{array}{l}\text { Husband } \\
\text { Outcomes }\end{array}$} & \multicolumn{4}{|c|}{ Weight Stigma } & \multicolumn{4}{|c|}{ Perceived Criticism } \\
\hline & Variables & $\beta$ & SE & $t$ & Variables & $\beta$ & SE & $t$ \\
\hline \multicolumn{9}{|l|}{ Depression } \\
\hline & (Constant) & & 5.43 & 2.069 & (Constant) & & 6.019 & .927 \\
\hline & Wife BMI & -.122 & .193 & -.938 & Wife BMI & .005 & .213 & .038 \\
\hline & $\begin{array}{l}\text { Weight } \\
\text { Stigma }\end{array}$ & -.297 & .211 & -1.002 & $\begin{array}{l}\text { Perceived } \\
\text { criticism }\end{array}$ & .130 & .665 & .469 \\
\hline & $\begin{array}{l}\text { BMI x } \\
\text { Weight } \\
\text { Stigma }\end{array}$ & .604 & .008 & $1.980^{*}$ & $\begin{array}{l}\text { BMl x } \\
\text { Perceived } \\
\text { criticism }\end{array}$ & .146 & .023 & .477 \\
\hline \multicolumn{9}{|l|}{ Self-Esteem } \\
\hline & (Constant) & & 3.21 & 5.535 & (Constant) & & 3.586 & 3.938 \\
\hline & Wife BMI & -.114 & .114 & -.886 & Wife BMI & .050 & .127 & .345 \\
\hline & $\begin{array}{l}\text { Weight } \\
\text { Stigma }\end{array}$ & -.287 & .125 & -.957 & $\begin{array}{l}\text { Perceived } \\
\text { criticism }\end{array}$ & .155 & .396 & .545 \\
\hline & $\begin{array}{l}\text { BMI x } \\
\text { Weight } \\
\text { Stigma }\end{array}$ & .553 & .005 & 1.792 & $\begin{array}{l}\text { BMI x } \\
\text { Perceived } \\
\text { criticism }\end{array}$ & .024 & .014 & .075 \\
\hline \multirow{5}{*}{$\begin{array}{l}\text { Marital } \\
\text { Satisfaction }\end{array}$} & & & & & & & & \\
\hline & (Constant) & & 9.55 & 9.211 & (Constant) & & 10.372 & 7.865 \\
\hline & Wife BMI & -.001 & .339 & -.007 & Wife BMI & .111 & .367 & .809 \\
\hline & $\begin{array}{l}\text { Weight } \\
\text { Stigma }\end{array}$ & .270 & .372 & .936 & $\begin{array}{l}\text { Perceived } \\
\text { criticism }\end{array}$ & .317 & 1.146 & 1.199 \\
\hline & $\begin{array}{l}\text { BMl x } \\
\text { Weight } \\
\text { Stigma }\end{array}$ & -.607 & .014 & $-2.046^{\star}$ & $\begin{array}{l}\text { BMI x } \\
\text { Perceived } \\
\text { criticism }\end{array}$ & -.717 & .040 & $-2.459 *$ \\
\hline \multicolumn{9}{|l|}{$\begin{array}{l}\text { Sexual } \\
\text { Intimacy }\end{array}$} \\
\hline & (Constant) & & 2.98 & 7.822 & (Constant) & & 3.190 & 6.543 \\
\hline & Wife BMI & .064 & .106 & .485 & Wife BMI & .219 & .113 & 1.566 \\
\hline & $\begin{array}{l}\text { Weight } \\
\text { Stigma }\end{array}$ & .046 & .116 & .153 & $\begin{array}{l}\text { Perceived } \\
\text { criticism }\end{array}$ & .200 & .352 & .738 \\
\hline & BMI x & -.320 & .004 & -1.034 & BMI $x$ & -.584 & .012 & -1.952 \\
\hline
\end{tabular}


Weight

Stigma
Perceived criticism

Husband's

rating of

wife's mate

value

\begin{tabular}{|c|c|c|c|c|c|c|c|}
\hline (Constant) & & 7.99 & 10.890 & (Constant) & & 8.665 & 8.858 \\
\hline Wife BMI & .016 & .284 & .126 & Wife BMI & .189 & .307 & 1.384 \\
\hline $\begin{array}{l}\text { Weight } \\
\text { Stigma }\end{array}$ & .498 & .311 & 1.723 & $\begin{array}{l}\text { Perceived } \\
\text { criticism }\end{array}$ & .693 & .957 & $2.614^{\star}$ \\
\hline $\begin{array}{l}\text { BMI x } \\
\text { Weight } \\
\text { Stigma }\end{array}$ & -.774 & .011 & $-2.602^{*}$ & $\begin{array}{l}\text { BMI x } \\
\text { Perceived } \\
\text { criticism }\end{array}$ & -1.034 & .034 & $-3.543^{\star \star *}$ \\
\hline
\end{tabular}

Husband's

rating of

how wife

matches his

(Constant)

$8.75 \quad 9.491$

(Constant)

$9.397 \quad 7.525$

ideal mate

\begin{tabular}{|c|c|c|c|c|c|c|c|}
\hline Wife BMI & .087 & .310 & .698 & Wife BMI & .279 & .332 & $2.088^{*}$ \\
\hline $\begin{array}{l}\text { Weight } \\
\text { Stigma }\end{array}$ & .686 & .340 & $2.405^{\star}$ & $\begin{array}{l}\text { Perceived } \\
\text { criticism }\end{array}$ & .869 & 1.038 & $3.353^{\star *}$ \\
\hline $\begin{array}{l}\text { BMI x } \\
\text { Weight } \\
\text { Stigma }\end{array}$ & -.980 & .012 & $-3.338 * \star$ & $\begin{array}{l}\text { BMI x } \\
\text { Perceived } \\
\text { criticism }\end{array}$ & -1.259 & .036 & $-4.409 * \star *$ \\
\hline
\end{tabular}

Note, * denotes significance at the $p<.05$ level, ** denotes significance at the $p<.01$ level, *** denotes significance at the $p<.001$ level. 
Table 2

Main effects and interactions for wife outcome variables

\begin{tabular}{|c|c|c|c|c|c|c|c|c|}
\hline \multirow[b]{2}{*}{$\begin{array}{l}\text { Wife } \\
\text { Outcomes }\end{array}$} & \multicolumn{4}{|c|}{ Weight Stigma } & \multicolumn{4}{|c|}{ Perceived Criticism } \\
\hline & Variables & $\beta$ & SE & $t$ & Variables & $\beta$ & SE & $t$ \\
\hline \multicolumn{9}{|l|}{ Depression } \\
\hline & (Constant) & & 6.88 & 3.383 & (Constant) & & 7.43 & 2.169 \\
\hline & Wife BMI & .151 & .244 & 1.150 & Wife BMI & .253 & .263 & 1.786 \\
\hline & $\begin{array}{l}\text { Weight } \\
\text { Stigma }\end{array}$ & .030 & .268 & .100 & $\begin{array}{l}\text { Perceived } \\
\text { criticism }\end{array}$ & .378 & .822 & 1.377 \\
\hline & $\begin{array}{l}\text { BMl x } \\
\text { Weight } \\
\text { Stigma }\end{array}$ & .161 & .010 & .519 & $\begin{array}{l}\text { BMI x } \\
\text { Perceived } \\
\text { criticism }\end{array}$ & -.158 & .029 & -.521 \\
\hline \multicolumn{9}{|l|}{ Self-Esteem } \\
\hline & (Constant) & & 2.62 & 5.948 & (Constant) & & 2.89 & 5.238 \\
\hline & Wife BMI & .111 & .093 & .859 & Wife BMI & .132 & .103 & .925 \\
\hline & $\begin{array}{l}\text { Weight } \\
\text { Stigma }\end{array}$ & -.143 & .102 & -.484 & $\begin{array}{l}\text { Perceived } \\
\text { criticism }\end{array}$ & -.010 & .320 & -.038 \\
\hline & $\begin{array}{l}\text { BMl x } \\
\text { Weight } \\
\text { Stigma }\end{array}$ & .375 & .004 & 1.232 & $\begin{array}{l}\text { BMI x } \\
\text { Perceived } \\
\text { criticism }\end{array}$ & .221 & .011 & .726 \\
\hline \multirow{5}{*}{$\begin{array}{l}\text { Marital } \\
\text { Satisfaction }\end{array}$} & & & & & & & & \\
\hline & (Constant) & & 6.62 & 9.584 & (Constant) & & 6.90 & 9.445 \\
\hline & Wife BMI & .013 & .235 & .096 & Wife BMI & .051 & .244 & .376 \\
\hline & $\begin{array}{l}\text { Weight } \\
\text { Stigma }\end{array}$ & -.078 & .258 & -.260 & $\begin{array}{l}\text { Perceived } \\
\text { criticism }\end{array}$ & -.227 & .763 & -.861 \\
\hline & $\begin{array}{l}\text { BMI x } \\
\text { Weight } \\
\text { Stigma }\end{array}$ & -.214 & .009 & -.695 & $\begin{array}{l}\text { BMI x } \\
\text { Perceived } \\
\text { criticism }\end{array}$ & -.200 & .027 & -.687 \\
\hline \multicolumn{9}{|l|}{$\begin{array}{l}\text { Sexual } \\
\text { Intimacy }\end{array}$} \\
\hline & (Constant) & & 3.06 & 9.578 & (Constant) & & 3.26 & 7.474 \\
\hline & Wife BMI & -.252 & .10 & -1.920 & Wife BMI & .025 & .115 & .176 \\
\hline & $\begin{array}{l}\text { Weight } \\
\text { Stigma }\end{array}$ & -.525 & .119 & -1.746 & $\begin{array}{l}\text { Perceived } \\
\text { criticism }\end{array}$ & -.030 & .360 & -.112 \\
\hline & BMI $x$ & .308 & .004 & .997 & BMI x & -.331 & .013 & -1.109 \\
\hline
\end{tabular}




\begin{tabular}{|c|c|c|c|c|c|c|c|c|}
\hline \multirow{3}{*}{$\begin{array}{l}\text { Wife's rating of } \\
\text { her mate value }\end{array}$} & \multicolumn{4}{|l|}{$\begin{array}{l}\text { Weight } \\
\text { Stigma }\end{array}$} & \multicolumn{4}{|l|}{$\begin{array}{l}\text { Perceived } \\
\text { criticism }\end{array}$} \\
\hline & & & & & & & & \\
\hline & \multicolumn{2}{|l|}{ (Constant) } & \multirow{2}{*}{$\begin{array}{l}9.54 \\
.339\end{array}$} & \multirow{2}{*}{$\begin{array}{l}8.179 \\
.663\end{array}$} & \multicolumn{2}{|l|}{ (Constant) } & \multirow{2}{*}{$\begin{array}{l}9.85 \\
.349\end{array}$} & \multirow{2}{*}{$\begin{array}{l}6.758 \\
2.294^{\star}\end{array}$} \\
\hline & Wife BMI & .085 & & & Wife BMI & .304 & & \\
\hline & $\begin{array}{l}\text { Weight } \\
\text { Stigma }\end{array}$ & .447 & .371 & 1.522 & $\begin{array}{l}\text { Perceived } \\
\text { criticism }\end{array}$ & .619 & 1.089 & $2.410^{*}$ \\
\hline & $\begin{array}{l}\text { BMI x } \\
\text { Weight } \\
\text { Stigma }\end{array}$ & -.736 & .014 & $-2.433^{\star}$ & $\begin{array}{l}\text { BMI x } \\
\text { Perceived } \\
\text { criticism }\end{array}$ & -1.104 & .038 & $-3.904^{\star \star *}$ \\
\hline \multirow{4}{*}{$\begin{array}{l}\text { Wife's rating of } \\
\text { how she } \\
\text { matches her } \\
\text { husband's } \\
\text { ideal mate }\end{array}$} & (Constant) & & 8.91 & 9.283 & (Constant) & & 9.22 & 7.284 \\
\hline & Wife BMI & .018 & .316 & .146 & Wife BMI & .289 & .326 & $2.227^{\star}$ \\
\hline & $\begin{array}{l}\text { Weight } \\
\text { Stigma }\end{array}$ & .418 & .347 & 1.454 & $\begin{array}{l}\text { Perceived } \\
\text { criticism }\end{array}$ & .732 & 1.019 & $2.907 \star \star$ \\
\hline & $\begin{array}{l}\text { BMI x } \\
\text { Weight } \\
\text { Stigma }\end{array}$ & -.734 & .013 & $-2.480 *$ & $\begin{array}{l}\text { BMI x } \\
\text { Perceived } \\
\text { criticism }\end{array}$ & -1.222 & .036 & $-4.404^{\star \star \star}$ \\
\hline
\end{tabular}

Figures 


\section{Illustrative Figure of Interaction between Wife BMI, Husband Weight Stigma, and}

Husband's Rating of How his Wife Matches his Ideal Mate.

\section{0}

Ideal Mate

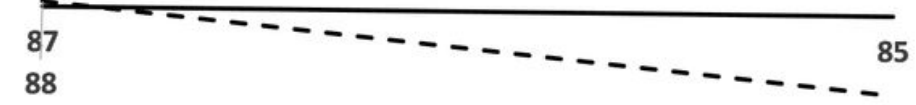

88

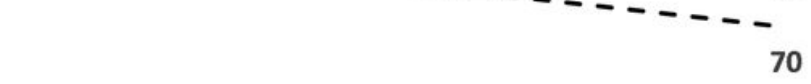

- Lower Husband Stigma

- - Higher Husband Stigma
Higher Wife BMI

Ideal Mate: Lower score = lower ideal mate; BMI: Low (<30), High ( $\geq 30) ;$ Husband Stigma: $1 S D \pm M$

\section{Figure 1}

An illustrative figure of the interaction between wife BMI, husband stigma, ideal mate ratings. 